\title{
Re-enactment leading to transformation: A critical assessment of the distinctives of Pentecostal preaching
}

\author{
Nel, Marius \\ North-West University \\ nel.marius1@gmail.com
}

\begin{abstract}
The article aims to define what the most distinctive characteristics of Pentecostal preaching are in order to assess these elements critically. Pentecostal preachers argue that their message is concerned with the Bible as the Word of God and its explication for modern-day listeners, but with the explicit purpose to perpetuate what the Bible says about the revelation of God as revealed to the contemporary preacher. The purpose of preaching is in other words that believers will experience an encounter with the same Spirit who revealed God to people in biblical times in order that presentday people will be saved, freed, healed and delivered in the same way as in apostolic times. Pentecostal preaching is described in terms of three elements, God's work in preaching, preparation for preaching, and the preaching event. The several aspects are described and discussed and some of the conclusions are that Pentecostal preaching should as non-negotiable be rooted soundly in Scripture, beginning from and focusing on the biblical text, while at the same time exegesis, although necessary academic work, may not be allowed to minimize the influence of the Spirit because the end of preaching is a word from God that produces the divine desired effect in the human situation. However, the emphasis on supernatural results leads in some instances to the manipulation of the context of preaching in order to gain the desired results, using emotionalism, mass suggestion, disorder, or showmanship.
\end{abstract}

Key words

Pentecostal preaching; biblical preaching; Holy Spirit; experience

\section{Introduction}

From its earliest days preaching had an important function within the Pentecostal movement as an explanation at the hand of the Bible of what 
God still wants to do for people, to touch them with his Spirit of power. ${ }^{1}$ Pentecostals inherited the Reformation form of preaching that is used generally in evangelical circles, consisting of the exposition of biblical passages (Dela Cruz 2010:121). However, they changed it from an orderly and reasoned discourse into a chaotic phenomenon with what seems to be all style and little substance (Johns 1998:3). The delivery style was subservient to the explicit aim of preaching, that was not merely to impart information or explain what a biblical passage means for the first listeners or even for today's readers, but primarily to build faith in the listeners' hearts to receive what God wants to give them (or what the preacher perceives it to be) and that correlates with what the people described in the Bible experienced (this element normally defines the invitation that ends the message). In this sense, Pentecostal preaching describes itself as prophetic (Jacobsen, 2003:46), where 'prophecy' is defined as the revelation of words that (allegedly) come from God (a Pentecostal definition of biblical prophecy as imagined in both the Old and New Testament; Bartlett 2012:26), applied to today's circumstances (Goldingay 2015:191) and related to God's overarching promises and purpose (Goldingay 2015:247). ${ }^{2}$ Prophecy is, in the words of John G. Lake (1994:49), the result of conceiving and understanding the real vision of Christ, whereby through union with him he takes possession of a person, reveals the power of God in and through that person, and in the process transforming other people and applying the power to their needs. 'These are the real truths of the Gospel. The Spirit witnesses to them when they are preached. The signs follow when this Gospel is preached' (Tomlinson [1913] 2006:102). And the Spirit is the force and means by which Jesus remains present in history and continues his work of inaugurating the kingdom (Boff 1985:150).

The question asked here is, what are the main characteristics of Pentecostal preaching that define it as distinctive from other traditions? Is it personality, style, preparation, results replete with signs, contents of the message, or

1 'Early Pentecostalism was shaped and carved out from its preaching and teaching... Pentecostals developed their oral theology and method of exegesis more through preaching than print' (Byrd 1993:203). Early Pentecostals were aware that the power of the Spirit is unleashed through orality, in witnessing and telling the stories of God's love (Dowd 1985:4).

2 Reformed preaching also defines preaching as prophetic but uses another definition for 'prophetic' that translates into the explication of the biblical message. 
a combination of all or the above (Holm 2003:15)? The diverse preaching styles among Pentecostal individuals and groups make it difficult to describe what is characteristic. When these distinctives are distilled from Pentecostal preaching practice - and it should be emphasized that it is not necessarily supposed that these characteristics are exclusive to Pentecostal preaching - it becomes possible to critically evaluate the practice for its effectiveness.

One finds in Pentecostal literature about preaching an emphasis on two elements, where the value of the written word for the preached word is underscored while at the same time attention is given to the Spirit's work in the preacher and among the congregation. In the interplay and balance between these two elements Pentecostal preaching should ideally take place. To find the balance between word and the revelation of the Word through the Spirit is the intricate task of the preacher.

The article utilizes language that focuses on the Spirit's work because in their analysis of preaching this forms an integral and important element for Pentecostals. The description of the work of the Spirit is not done in exclusive terms as though Pentecostal preaching can make a special claim to the work of the Spirit. ${ }^{3}$

The article endorses unapologetically the idea that God is (or can be) actively involved in the process of preaching, ${ }^{4}$ and that his involvement distinguishes preaching from mere speech. An important indicator of the success of the preaching event is the results in terms of people getting saved, the sick getting healed and believers being encouraged and edified, as described of apostolic preaching in the New Testament (e.g., Acts 3:2-8; $4: 30 ; 8: 6-7)$. The pragmatic factor serves as a tool to evaluate Pentecostal preaching; if listeners did not experience what the message explained the sermon was not successful.

3 Neurotheology is providing significant insights on regions of the cerebral cortex associated with spiritual experiences. The cerebral cortex gives humans the intellectual capability to build social constructs through, among others, religious means. As an important center for sensory and motor integration, the cerebral cortex, along with its neural connections to primordial structures, enables humans to experience phenomena that transcend the physical boundaries of reality (Liu 2011:22). Pentecostal experience can be explained in these categories; however, the present article limits itself to a theological analysis of Pentecostal preaching.

4 'Preaching is based upon this one assumption' (Johns 2003:52). 
Johns (2003:45) argues that it is impossible to describe a Pentecostal sermon while utilizing Enlightenment criteria (such as the elevation of reason, drive for clarity, the human as exclusive subject, and belief in sameness) because Pentecostal worship with its highly dynamic and experiential liturgy has been found metaphysically incorrect. The result is a lack of adequate language with which to convey the dynamics of preaching within a Pentecostal worship service. What is needed is a new homiletical paradigm that allows for greater emphasis on the inductive (rather than deductive) and mysterious nature of preaching and its effects and that can correctly describe 'anointed preaching' (Byrd 2015:284). This paradigm is in Willimon's (1998:19) view accommodated by postmodernism's return to supernaturalism (so also Johns 1995:74-81) toward the ancient worldview expressed in the New Testament in reaction to modernity's claim that everything in the world is capable of being known by anyone who is reasonable with nothing miraculous, gifted or unavailable to be added to the natural world from outside the known order.

\section{Distinctives of Pentecostal preaching}

In order to distil what may be described as the distinctive characteristics of Pentecostal preaching it is viable to describe a Pentecostal homiletics. ${ }^{5}$ While the concepts, structures and methodologies of other confessions that are not Pentecostal provide a great deal of material utilised in Pentecostal homiletics, it is possible to identify a few factors that do not play a part in non-Pentecostal circles and that form the unique element in Pentecostal preaching. For Pentecostals, the sermon (or rather, message) invites the listener to experience the power and truth of the Word proclaimed. The implication is that there is a certain immediacy to the Word proclaimed (Byrd 2015:272). A message about healing in a Pentecostal church invites listeners to experience the present healing power of Christ who still heals today, illustrating the Pentecostals' approach to revelation, hermeneutics

5 The supposition is that there is a distinct Pentecostal approach to homiletics with unique presuppositions fit for the unique worship contexts that occur only in 'Pentecostal' churches. However, Pentecostal presuppositions about revelation are not disconnected from the larger body of theological confessions, making it improbable to claim a distinct Pentecostal homiletics, although it must be acknowledged that Pentecostalism raises important issues not considered in non-Pentecostal homiletics (Byrd 2015:271272). 
and proclamation. The unique Pentecostal emphasis in the preaching event can be described in terms of the three different elements of the preaching endeavour, God's work in preaching, the preparation for preaching the message and the preaching event itself (Waldholm 2015:266-267).

\section{God's work in preaching}

Pentecostals agree that all believers receive an enduement of the Spirit, allowing non-Pentecostal preachers to be enabled by the Spirit to preach the gospel effectively (Crabtree 2003:30) although they will not be as bold and spiritually 'connected' as Pentecostals are (Holm 2003:21). However, they claim that Spirit baptism brings a 'special enduement of power' that can be traced back to the events of the Day of Pentecost (Acts 2) and that provides power to witness in preaching, leading to supernatural results (Crabtree 2003:35-41). It seems as if Pentecostals imply that their preaching would be more powerful and effective than the preaching of somebody who has not experienced Spirit baptism and the initial sign of speaking in tongues, ${ }^{6}$ a claim that has not been verified empirically. It might be the result of arrogance, haughtiness and even pride when Pentecostals place their preaching in a category of its own, caricaturing evangelicals as a group focused on an intellectual faith merely based upon propositions (Heisler 2004, 2007), without discounting the fact that the first disciples exorcised demons and witnessed healings through their ministry before the Day of Pentecost (Mk 6:13-14; Lk 9:1-6; 10:1-19). Those who have not experienced Spirit baptism (in terms of how Pentecostals define it) should not be understood as lacking the potential for supernatural results in their preaching (as Billy Graham and others demonstrated). Tongue-speaking Pentecostals do not have exclusive access to God's anointing or his Spirit (Holm 2003:23-24).

Secondly, the authority of the Bible is presupposed by Pentecostals. Some Pentecostals describe the Bible as inspired by the Spirit, inerrant, and infallible, proceeding from God and therefore invested with divinity that makes it authoritative and efficient (Crabtree 2003:46-47; Samuel

6 The article is written from the perspective of the classical Pentecostal movement which accepts that speaking in tongues is the (initial) sign of Spirit baptism, although other opinions are also held. 'Classical Pentecostals' refer to those who historically date their origins to the beginning of the twentieth century. 
2013:202). However, although most Pentecostals hold a high view of Scripture they do not build their theology primarily on the Bible but they find in the Bible a precedent to be repeated and re-enacted in the lives of contemporary believers (Archer 2009:140-156). Like Barth they define the use of theology as servant to preaching (Willimon 1998:15); all theology is tested by its practice. ${ }^{7}$ The text of Scripture is not one-dimensional (Johns 2003:48). The Protestant dictum sola Scriptura is revised to Spiritus-Word, and Scripture is understood within the context of the ongoing revelation of God by his Spirit. The Spirit is not made a prisoner to the Word, limited to speaking scripturally but the Spirit is liberated to speak to the church in many ways (Moore 2000:12-14). Pentecostals do not define doctrine from the narratives about the early Church but they use these narrative as a model for what they expect to experience themselves, in their meeting with God through his Spirit. Purity of doctrine is then preserved by checking to see that the witness of what the contemporary disciple has experienced conforms to the primary 'witness' of Scripture (MacDonald 1976:61). The Bible is directly interpreted through the experience of God in daily life (Dela Cruz 2010:105). This hermeneutic filtered through experiential criteria requires that the events of salvation be re-enacted in the lives of contemporary believers (Olson 1999:491). The implication is that the Bible as such does not have authority; authority comes from the Spirit enlivening the Word in the revelation of Jesus Christ to the contemporary believer in the same terms as to people described in the Bible.

The problem posed by this viewpoint is that strange doctrines can easily be (and are) imported, and Pentecostals do not necessarily utilize Scripture consequently to test it, as one finds the Jesus Only heresy, cultic influences through the teaching of E.W. Kenyon, prosperity theology, and the overemphasis on angels that functions in parts of the Pentecostal movement. Pentecostals tend to place experience and extra-biblical revelation above the Bible (Enyinnaya 2008:146), exposing themselves to such heretical teachings as well as abuse by emotionally unstable persons. Pentecostals' anti-intellectualism, fundamentalism, pietism, and disdain for formal theological training are a backlash against the traditional

7 Barth (1969:272) writes that you will not be far from the kingdom if you always think of preaching as you are told to think of manna in Exodus 16, as a gift from heaven that needs to be picked up each time afresh. 
Western (and Protestant) modernist obsession with logic, academics, and science (Johns 1998:3; Enyinnaya 2008:147) while Pentecostals value God's direct revelation, in many instances apart from the corrective of biblical exegesis and exposition. While modernism's excesses should be avoided it is important that faithfulness to Scripture should be emphasized.

Land (2010:39) admits that the objection that Pentecostals place the Spirit above the Word and thus elevate experience to become the norm is true and that its effects could be (and are in practice) damaging to truth. But he adds that Pentecostals argue that the Spirit is prior to the Word and inspires and illumines that Word within the communion while gifting and guiding persons in the community. 'Because of the ongoing ministry of the Holy Spirit, the text of scripture, as written word, is alive and powerful' (Johns 1998:5) leading to signs and powers of the Spirit which may not be regarded as an optional addition to the church.

Thirdly, Pentecostals emphasize that the message in preaching originates in God, not in the prophet. Pentecostal preachers prefer to refer to their preaching as 'messages' rather than 'sermons' to illustrate their reliance upon the Spirit to supply them with an inspired message suitable for each unique occasion. ${ }^{8}$ And they regularly use prophetic terminology in their ministry, for example, 'I have a message that the Lord has laid on my heart, that God deposits in my spirit' (Sheppard 2001:64), and they pray and allow that the Spirit will move powerfully to make their preaching effective, with the resultant signs and wonders. Sometimes they refer to their messages

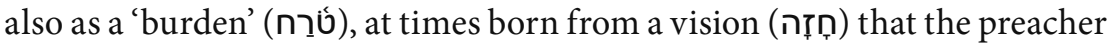
received, normally during times of prayer (and fasting). And while the Pentecostal preacher would agree that study is necessary in order to build an effective sermon and that knowledge of the socio-historical context of the Scripture passage is essential, it is emphasized that neither study nor insight can give birth to a prophetic message (Bishop 1983:27). They argue that study of the Scripture and dependence upon the Spirit for explaining the passage are not mutually exclusive but rather complement each other in preparation of the message, resulting in preaching 'prophetic Scripture' (Hayford 2006:77).

8 And to distinguish it from Protestant preaching that they regard and perceive as formalistic and lifeless even when it is based on sound exegesis. 
In order to interpret texts as literally as possible many Pentecostals ignore the temporal, cultural and historical gap that exists between the biblical text and the contemporary reader. When the text is read and interpreted without utilizing available knowledge about the author and his/her relation to the readers, the first readers and their situation, and the culture and history behind the text misunderstanding may (and does) occur. Some Pentecostals in their disdain of formal theological education deny themselves knowledge of hermeneutical and exegetical tools and resources while this knowledge is necessary in combination with the anointing of the Spirit in interpreting the word of God.

Pentecostal preaching is and should be rooted soundly in Scripture, beginning from and focusing on the biblical text (Hughes 2004:132). This should be regarded as non-negotiable. God's role in preaching is that he has spoken through Scripture; in order for the preacher to uphold what God has communicated, he or she must preach the Scriptures or at least stay within its boundaries (Robinson 2001:20).

\section{Preparation for preaching}

Most Pentecostal denominations have as a precondition for entrance into the ministry that preachers must be able to witness to a call (e.g., Burger \& Nel, 2008:140), and as a result many Pentecostal preachers' call narrative deliberately bear similarities to the call narratives of the prophets of the Hebrew Bible (Heschel 2001:I:28), filling them with a compelling urge to proclaim the divine word (Hubert 1983:17). The divine call serves for the preacher as the beginning of a new life dedicated to the preaching ministry because it is interpreted as divine authorization and ordination for ministry by the church and the individual. It can be argued that a person's call experience is subjective and one's ministry cannot be built upon an emotionally loaded experience. However, many seemingly successful ministries were and are built upon such testimonies.

The call narrative for Pentecostals must always necessarily include the experience of Spirit baptism which is seen to serve as the quintessential encounter that transforms the believer as well as the initial sign of being filled with the Spirit (Hayford 2006:63; Moore 2011:58-59), resulting in a reordering of life in terms of a new spirituality filled with apocalyptic expectation and urgency (Land 2010:50-63). The experience of Spirit 
baptism is perceived as the motivation for bold witness in Pentecostal preaching (Dela Cruz 2010:121). Spirit baptism reveals according to Pentecostals the revelation and truth of Christ, accompanied by the supernatural demonstration of his power, implying its absolute necessity for the preacher (Crabtree 2003:205). It is the filling with the Spirit that enables the preacher to proclaim a Spirit-inspired and Spirit-anointed message with boldness and effectiveness (Seymour [1915] 2006:54-55; Martin, 2015:47), amounting to the preacher being endued with authority to preach (Lk 24:9). And men and women alike experience the call (Parham [1911] 2006:36-38; Stevens 2006:284).

Authority to preach is derived on the one hand from the call resulting in a personal relationship with Christ and on the other hand from Scripture, although Pentecostals argue that more emphasis should be on the internal work of God in the life of the preacher, allowing him or her to speak with power rather than to the external authority of Scripture as the source of authority in preaching (Samuel 2013:204). This underlines the necessity that prayer should ground preaching ${ }^{9}$ although it should be remembered that the amount of time they spend in prayer does not necessarily determine the level of anointing in their preaching (Phil 2:12-13; Holm 2003:22). 'Let's come to the pulpit fresh from an experience with God!' advises Wood (2010). The implication is that the proclamation of the Bible should be accompanied by an anointing of the Spirit that serves as a precondition for the proclamation to be effective and successful, a viewpoint that most Protestants would not hold because in their opinion the authority behind preaching resides in the biblical text and not the preacher (Robinson 2001:24).

It is expected of the preacher to maintain a healthy spiritual life, in Pentecostal parlance to be continually filled with the Spirit. Crabtree (2003:110-112, 118-121) explains that it is imperative for a Pentecostal preacher because it leads to a Spirit-filled character and mind, displaying the fruit of the Spirit and being in continual communication with God. Pentecostal preachers experience what they call 'the anointing' where they

9 The preacher's prayer can be more important than Bible study because the inspiration from the Holy Spirit determines how he interprets and applies scriptures in his sermons, Wood teaches (2010). 
act beyond themselves in following the guidance of the Spirit that serves as vehicle of a revelation coming to the preacher, sometimes without any preparation, as a word of wisdom or knowledge (Hughes 1981:22-23).

Pentecostals emphasize that the goal of Pentecostal preaching is not to stimulate listeners intellectually or entertain them but to transform their affections, leading to a new lifestyle (Boone 1996:134; Heath \& Heath 2008:168; Duarte 2010:180-181; Guillame 2011:221). Pentecostal preachers enact the Word of God in order for their listeners to experience an encounter with God that will lead to life transformation, in the same order as that experienced by the preacher and based on what the biblical characters experienced. This does not mean that the message will not include information and argument, but the difference is that the purpose of the message is not to inform but to transform, including affections and will. This does not necessarily mean that Pentecostals equate emotions with spirituality (Holm 2003:27), although it may be true in many instances. However, Pentecostals agree that emotions should be the natural by-products of any genuine experience with God in a healthy spirituality (MacDonald 1976:64), producing spiritual depth and a concomitant change of life and attitudes (Enyinnaya 2008:151). The test for true spirituality is a changed lifestyle in agreement with New Testament requirements.

Many contemporary Pentecostals would agree that exegesis including a historical, grammatical, and literary study of a passage in its context is necessary, with the help of resources such as lexicons, concordances, commentaries, and etc. They fear, however, that academic work in exegeting the text may minimize the influence of the Spirit because, they argue, the Bible is not automatically and mechanically the word of God but only becomes the word when the lifegiving power of the Spirit assimilates, enlivens, and transmits it (Cronjé 1981:47). The end of preaching is not simply good exegesis; it is a word from God that produces the divine desired effects of transformation in the human situation (Holm 2003:25).

Pentecostal hermeneusis therefore tends not to spend much time in exegeting a text in a historical-critical manner but rather focuses on the immediate meaning of a text (Byrd 1993:205). What the text meant in its original cultural context is less important for Pentecostals looking for the link with the contemporary situation and its application in daily life. This 
hermeneutic constantly reinforces the conviction that the spiritual and extraordinary supernatural experiences of biblical characters need to be re-enacted in the lives of contemporary believers (McPherson 1946:195; Williams 1953:41). Pentecostal preaching requires a theory and a method of hermeneutics that facilitate a 're-experiencing' of the biblical text while maintaining respect for the text within its historical context (Byrd 1993:205). This is a shortcoming that weakens Pentecostal preaching's faithfulness to the biblical text.

By expecting historical biblical events to be re-enacted in the contemporary church leading to biblical signs and wonders repeated in modern times, Pentecostals' worldview allowing for supernatural intervention and miracles stands in stark contrast to a scientific worldview that does not allow for any supernatural phenomena to occur outside the accepted system of indictable cause and effect (Lataster 2013:31). Pentecostals need to discount the sustainability of their clearly anti-scientific worldview in times when some signs and wonders (such as miraculous healings) are scientifically tested and found wanting, apart from placebo cures from psychosomatic illnesses (Morton 2012:110).

Pentecostal epistemology can be criticized as naïve because it uncritically adopts the first-century worldview with all its corollaries, allowing for God's control over believers' daily lives and his involvement in their affairs. Pentecostal epistemology and hermeneutics require that a positivistmechanistic view and a rationalist-modernist philosophical paradigm be renounced in order to interpret the Bible, a requirement that cannot be sustained over the long term.

Cargal (1993:173) in his discussion of worldviews proposes that what Pentecostals need is an epistemology rooted in the criteria of empirically verifiable sensory experience (such as healings or other so-called miraculous events) and that does not violate the coherence of rational categories because it is not viable to live in a Western culture with an epistemology and its corollary worldview from the first century or even earlier.

However, not all agree with this view. Johns (2003:45), as indicated above, argues that Pentecostal preaching is unique and needs a distinctive and specific paradigm to describe its essence, and that postmodernism's seeming return to supernaturalism which is the ancient worldview 
accommodates this paradigm (cf. Duduit 2006:123). In Pentecostals' Godcentered worldview all things relate to God and God relates to all things, and the natural world is always potentially a vehicle for the visitation of the supernatural (Johns 1995:73-96). While the Protestant Reformation's paradigm centres around the recognition that humans are sinners, who stand guilty and condemned before a just God but that the death and resurrection of Jesus offers forgiveness as a free gift, and justifies and sustains believers, Pentecostals' message has a further and different focus: It also centres on the meaning of the life, death and resurrection of Jesus, but then leading to and culminating in the manifestation of the Spirit leading to believers' living from Jesus' daily presence (Shaull 1998:8).

What is critical in Pentecostal preaching seems to be that a correct biblical theology of pneumatology and bibliology must drive and undergird the methodology of homiletics in order to ensure that the Spirit's work in all aspects of preaching is recognized (Heisler 2004:2). In terms utilized by 1 Corinthians 2:1-5, preaching should not depend on lofty speech or wisdom

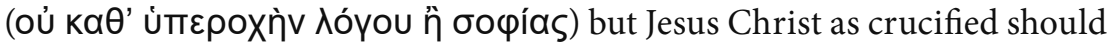
be the sole focus. To be effective, preaching should be in demonstration

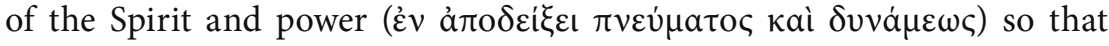
listeners' faith will not rest in the wisdom of men but in the power of God.

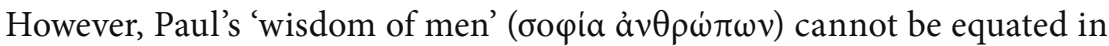
an unqualified manner with academic scholarship, as Pentecostals did in the past. Higher education should not come into conflict with the leading of the Spirit, although the potential for such a possibility would always exists (Holm 2003:20) and a written manuscript to guide the preacher in the pulpit should not necessarily squelch the leading of the Spirit (Holm 2003:20).

It should be non-negotiable that Pentecostals' sometimes excessive emphasis on the present work of the Spirit and the supernatural should be counterbalanced by serious exegetical labour unlocking the text in its sociohistorical context. It is suggested that Scripture should provide the borders within which Pentecostal preaching limits itself. Samuel (2013:214) is correct in his observation that a more balanced Pentecostal approach to preaching is needed today, one that incorporates the Spirit's inspiration of the Bible and his present work in preaching. Enyinnaya (2008:148) in a simplistic way describes Pentecostal hermeneutics as reader-centred (contra 
text-centred and author-centred) due to its emphasis on experience and extra-biblical revelation apart from the Bible and as resources to interpret the Bible, making the Bible only a tool to validate experience. Pentecostals need to revisit their hermeneutics in order to define its principles.

\section{Preaching event}

For Pentecostals the most important part in the act of preaching lies in the results, including the experience of salvation, Spirit baptism, healing and other miracles, and the manifestation of gifts of the Spirit (Ragoonath 2004:37, 75). ${ }^{10}$ These signs serve as some kind of hermeneutical criterion for Pentecostals' preaching and teaching (Enyinnaya 2008:146). The phenomenon of supernatural results forms the defining element that sets Pentecostal preaching apart from other evangelical entities (Crabtree 2003:135), requiring sensitivity to the leading of the Spirit and an expectation of his direct involvement in the preaching event.

Pentecostals do not always acknowledge that not all 'supernatural' occurrences come from the Spirit. The warning in Matthew 24:24 is relevant, that false christs and false prophets will arise and perform great signs and wonders, so as to lead astray, if possible, even the elect.

The idea persists among Pentecostals that if preaching is not accompanied by supernatural results it is not effective. Johns (2003:50) describes the role of the supernatural in Pentecostal preaching, that the preaching of the word should bring about the reality described in the text. The pressure on Pentecostal preachers to produce supernatural results in line with the passage that they preach from leads in some instances to the manipulation of the context of preaching in order to gain the desired results from the preached word. Thus they may use 'hype' and emotionalism in order to get people to respond to the altar call, mass suggestion in order for people to be 'slain in the Spirit' or experience Spirit baptism (Samuel 2013:213), excessive noise, activity, motion, disorder, or showmanship (Holm 2003:18).

10 Enyinnaya (2008:146) describes the teaching of a part of Nigerian classical Pentecostalism when he states that prosperity consisting of physical wholeness and financial prosperity also functions as part of the signs of successful and effective Pentecostal preaching, a viewpoint that cannot be accepted when the Bible is read in terms of current biblical scholarship and that Enyinnaya (2008:150) also criticizes as the root of many erroneous interpretations emanting from the circles of the health and wealth proponents. 
The temptation for Pentecostals may be to focus exclusively on the supernatural and ignore other challenges such as the inequality underlying the local community, poverty, the needs of the physically or mentally challenged, or Aids orphans. And they may also lose the perspective that preaching do not always lead to immediate gratification because in some instances it may only bear fruit in the future, when the church reaches its ultimate goal of perfection (Chan 2006:39).

When the guidance of the Spirit is followed it leads to spontaneity where the preacher may stop the message to pray for healing or give an invitation for members to bring testimonies. From the beginning Pentecostals left room in worship services for people to testify about their encounters with God and testimonies play an important role in illustrating the truths distilled from scripture (Yeung 2011:59). Testimonies reflect the fact that theological teaching in sermons initiates experience, including Spirit baptism (Yeung 2011:68). Jacobsen (2006:5) argues that Pentecostalism serves as a protest against the use of religious words without religious experiences to back them up, a protest against perceived theological shallowness.

The Pentecostal tradition conceives of the Church as a community of prophets (Waddell 2006:127-129; Stronstad 2010:72). Prophecy does not emerge from or through individuals but from within the body of Christ, and the preacher is one prophet among many Hughes (2004:129-130) roots Pentecostal prophetic preaching in Joel 2:28-30's inclusivity of the community of believers). For most Pentecostals, as is the case among Protestants, the congregation's role in the development of the sermon is primarily passive. The message may appeal to their affections and require them to respond to an invitation, and they may respond and interact to the message with 'hallelujah!' and 'amen!' (Byrd 1993:204). But Pentecostals should purposefully acknowledge that the congregation has been endued with gifts of the Spirit (1 Cor 12:1-5 refers to these gifts as $\pi v \varepsilon v \mu \alpha \tau \iota \kappa \tilde{\omega} v, \chi \alpha \rho \iota \sigma \mu \alpha \dot{\tau} \omega v, \delta\llcorner\alpha \kappa o v \iota \tilde{\omega} v$, and $\dot{\varepsilon} v \varepsilon \rho \gamma \eta \mu \alpha \dot{\tau} \omega v)$ as priests and prophets (as Land 2010:18; Kärkkäinen 2007:11 emphasize), leading to their free participation in all structures and a resultant democratization of liturgy, worship and preaching (Hollenweger in Hudson 2001:42) with a transparent, non-hierarchical corporate structure (Armstrong 2006:88). In order to incorporate the giftedness of Spirit-filled members, preachers may form a team that prepares for the preaching event and consists of a cross- 
section of the congregation, to help in the development of the message. The various gifts of the Spirit encompassed in the team will contribute in ways that will complement the preacher's (limited) gifting and provide insights into blind spots that characterize the preacher's limited perspective (Young 2006:246-248).

The congregation can also be involved in the delivery by the established custom of 'call and response', a pattern of verbal interplay between the preacher and congregation that helps shape the message's delivery (Smith 2008:297). Progressional dialogue may also be utilized, involving the intentional interplay of multiple viewpoints that may lead to unforeseen and unexpected ideas (Pagitt 2005:52), a practice going back to William Seymour's (1870-1922) ministry at Azusa Street when he invited others to respond and participate in his sermons (Byrd 1993:204; Robeck 2006:115119).

Preachers are not infallible and whenever a person claims to speak on behalf of God, the claim must be subject to a process of discernment. Preaching invites prayerful scrutiny by the community of believers (Sheppard 2001:64). Preaching should be done to please and honour God; the temptation should be avoided to pander to every opinion in the congregation (Samuel 2013:215). ${ }^{11}$ Discernment is not always an easy task because of the difficulty one might experience to discern truth from error (Moore, 2011:86-100). It calls for a body of people who are formed in the Spirit where each one is bearer and hearer of the Spirit (Johns 2003:50). And it should also be held in mind that the true prophet's message will seldom be popular, as demonstrated by biblical prophets' rejection by their peers and Jesus' crucifixion. The prophetic preacher may experience negative responses and criticisms of the message (Mt 5:11-12).

A last element that needs to be discussed is the delivery style in Pentecostal preaching. Effectiveness of sermons depends partly on the preacher's style, consisting of the arrangement of thoughts, use of voice and gesture, and means to involve listeners such as 'call and response' discussed above. Pentecostal preaching has been defined as the dissemination of truth through personality (Allen 1961:12), and this aspect should be kept in

11 Enyinnaya (2008:151) calls this a listener-friendly disposition or public relations concern that makes Pentecostal (and other) preaching open to much suspicion. 
mind. Pentecostal preaching is normally delivered with passion and an abundance of affective language (Hughes 1981:144). The use of passionate language and unconventional methods led to Pentecostal preachers being characterized as fanatics, although more recently some of them have adopted a more refined style of delivery to reach new niche markets (Leoh 2006:45). What is important is that Pentecostal preaching should not adopt preaching models that are not compatible with their paradigm and hermeneutical orientation that determines that the message should happen in the lives of listeners before it is effective (Green 2015:59).

\section{Conclusion}

Pentecostal preachers see as the purpose of their message an explanation and illustration at the hand of the Bible of what God still wants to do for people today, to touch them with his Spirit of power in order to save, free, heal, and deliver them. For this reason preaching is not primarily concerned with what a biblical passage means but wants rather to facilitate an experience that concurs with the experience of the people of which the Bible tells.

Pentecostal preaching is described in terms of God's work in preaching, preparation for preaching, and the preaching event. God's work firstly consists of baptizing the preacher with the Spirit enduing him or her with power to witness in preaching, and resulting in supernatural consequences. Secondly the Spirit should be allowed to work freely. The Spirit is not made a prisoner to the Word and limited to speaking scripturally but the Spirit is liberated to speak to the church in many different ways. However, this causes some Pentecostals to tend to place experience and extra-biblical revelation above the Bible, in this way exposing themselves to heretical teachings. Thirdly, the message in preaching should originate in God, not in the prophet. While the Pentecostal preacher would agree that study is necessary in order to build an effective sermon, neither study nor insight can give birth to a prophetic message. However, it is concluded that Pentecostal preaching as non-negotiable should always be rooted soundly in Scripture, beginning from and focusing on the biblical text.

Pentecostals believe that preachers should have a divine call before they are allowed to preach and the call narrative must always necessarily include the 
experience of Spirit baptism. Authority to preach is derived from the call that should result in a personal relationship with Christ as well as Scripture as the sources of authority in preaching. The anointing of the Spirit serves as a precondition for the proclamation to be effective and successful because the goal of Pentecostal preaching is to transform people. Pentecostals accept that exegesis is necessary but share the fear that academic exegetical work may minimize the influence of the Spirit. The end of preaching is not simply good exegesis but rather to present a message that leads to the transformation of the human situation. Pentecostal epistemology adopts the first-century God-centered worldview that the natural world is always potentially a vehicle for the visitation of the supernatural.

Lastly, the preaching event is described in terms of its results, including conversions, signs and wonders that serve as hermeneutical criteria for Pentecostal preaching. However, not all 'supernatural' occurrences necessarily comes from the Spirit, and the pressure on Pentecostal preachers to produce supernatural results may lead to manipulation in order to gain the desired results from the preached word while they may also focus exclusively on the supernatural and ignore other existential challenges faced by the surrounding community. It is also argued that the congregation as a community of prophets should be involved in the delivery while they should apply discernment about the truth of the message.

\section{Bibliography}

Allen, CL 1961. Pentecostal preaching is different. Los Angeles: L.I.F.E.

Archer, KJ. 2009. A Pentecostal hermeneutic: Spirit, scripture and community. Cleveland: CPT.

Armstrong, C 2006. 'Embrace your inner Pentecostal.' Christianity Today September: $86-89$.

Barth, K 1969. Church dogmatics: The doctrine of the word of God. Edinburgh: T\&T Clark.

Bartlett, M 2012. 1 Corinthians. The Pentecostal Bible Commentary Series. Nashville: Thomas Nelson. 
Bishop, DS 1983. 'A competent workman,' in Fisher, RE (ed.) Pressing toward the mark, 27-59. Cleveland: Pathway.

Boff, L 1985. Church: Charism and power. New York: Crossroads.

Boone, RJ 1996. 'Community and worship: The key components of Pentecostal Christian formation.' Journal of Pentecostal Theology 8:129-142.

Burger, I \& Nel, M 2008. The fire falls in Africa: A history of the Apostolic Faith Mission of South Africa. Vereeniging: Christian Art.

Byrd, J 1993. 'Paul Ricoeur's hermeneutical theory and Pentecostal proclamation.' Pneuma 15(2):203-214.

Byrd, J.K. 2015. 'Pentecostal homiletic: A convergence of history, theology, and worship,' in Martin, L.R. (ed.) Toward a Pentecostal theology of preaching, 270-288. Cleveland: CPT.

Cargal, T 1993. 'Beyond the fundamentalist-modernist controversy: Pentecostals and hermeneutics in a postmodern era.' Pneuma 15(2):163-187.

Chan, S 2006. Liturgical theology: The church as worshiping community. Downers Grove: InterVarsity.

Crabtree, CT 2003. Pentecostal preaching: Empowering your pulpit with the Holy Spirit. Springfield: Gospel.

Cronjé, FHJ 1981. Waarom Pinkster: Die rol van die Heilige Gees in die ontstaan van die Nuwe Testamentiese kerk, en die leer oor saligheid. Johannesburg: Evangelie.

Dela Cruz, RG 2010. 'Preaching among Filipino Pentecostals and exposition through testimonial hermeneutics: A positive contribution of the PGCAG to evangelicalism in the Philipines.' Asian Journal of Pentecostal Studies 13(1):98-123.

Dowd, M 1985. 'Contours of a narrative Pentecostal theology and practice.' Paper presented at the $15^{\text {th }}$ annual meeting of the Society for Pentecostal Studies, Mother of God Community, Gaithersburg. 
Duarte, N 2010. Resonate: Present visual stories that transform audiences. Hoboken: John Wiley.

Duduit, M 2006. 'Preaching to postmoderns: An interview with Brian McLaren,' in Duduit, M (ed.) Preaching with power: Dynamic insights from twenty top pastors, 118-126. Grand Rapids: Baker.

Enyinnaya, JO 2008. 'Pentecostal hermeneutics and preaching: An appraisal.' Ogbomoso Journal of Theology 13(1):144-153.

Goldingay, J 2015. An introduction to the Old Testament: Exploring text, approaches \& issues. Downers Grove: IVP Academic.

Green, CEW 2015. 'Transfiguring preaching: Salvation, mediation, and proclamation,' in Martin, L.R. (ed.) Towards a Pentecostal theology of preaching, 64-81. Cleveland: CPT.

Guillame, S 2011. 'Prediking in 'n multimedia-kultuur: Homiletiese beginsels vir 'n interaktiewe kommunikasiepraxis.' Ned Geref Teologiese Tydskrif 52(1-2):214-224.

Hayford, J 2006. The charismatic century: The enduring impact of the Azusa Street revival. New York: Hachette.

Heschel, AJ (1962) 2001. The prophets. 2 vols. Perennial Classics. New York: Harper.

Heath C \& Heath, D 2008. Made to stick: Why some ideas take hold and others come unstuck. London: Arrow.

Heisler, G 2004. 'Clark Kent or Superman? A case for a Spirit-driven methodology of expository preaching.' Paper presented at annual meeting of the Evangelical Academy of Homiletics, 2004. [Online]. Available: http://www.ehomiletics.com/papers/04/heislero4.php [Accessed 2016-08-05].

Heisler, G 2007. Spirit-led preaching: The Holy Spirit's role in sermon preparation and delivery. Nashville: B.\&H.

Holm, R 2003. 'Cadences of the heart: A walkabout in search of Pentecostal preaching.' Didaskalia Fall:13-27. 
Hubert, H 1983. 'Clarifying the call,' in Fisher, R.E. (ed.) Pressing toward the mark, 9-26. Cleveland: Pathway.

Hudson, N 2001. 'Pentecostalism, past, present and future: Interview with Walter Hollenweger.' Journal of the European Pentecostal Theological Association 21:41-48.

Hughes, RH 1981. Pentecostal preaching. Cleveland: Pathway.

Hughes, RH 2004. Pentecostal preaching. Second edition. Cleveland: Pathway.

Jacobsen, D 2003. Thinking in the Spirit: Theologies of the early Pentecostal movement. Bloomingham: Indiana University Press.

Jacobsen, D 2006. A reader in Pentecostal theology: Voices from the first generation. Bloomington: Indiana University Press.

Johns, J 1995. 'Pentecostalism and the postmodern worldview.' Journal of Pentecostal Theology 7:73-96.

Johns, CB 1998. 'What can the mainline learn from Pentecostals about Pentecost?' Journal for preachers Lent:3-7.

Johns, C 2003. 'What makes a good sermon: A Pentecostal perspective.' Journal for preachers 26(4):45-54.

Johns, JD 1995. 'Pentecostalism and a postmodern worldview.' Journal of Pentecostal theology 7:73-96.

Kärkkäinen, V-M 2007. 'Encountering Christ in the Full Gospel way:' An incarnational Pentecostal spirituality.' Journal of the European Pentecostal Theological Association 27(1):5-19.

Lake, JG 1994. John G. Lake: His life, his sermons, his boldness of faith. Fort Worth: Kenneth Copeland Publications.

Land, SJ 2010. Pentecostal spirituality: A passion for the kingdom. Cleveland: CPT.

Lataster, RC 2013. There was no Jesus, there is no God: A scholarly examination of the scientific, historical, and philosophical evidence \& arguments for monotheism. CreateSpace Independent Publishing Platform. 
Leoh, V 2006. 'A Pentecostal preacher as an empowered witness.' Asian Journal of Pentecostal Studies 9(1):35-58.

Liu, YA 2011. 'Touched by God: A neural basis for the Pentecostal spiritual experience.' [Online]. Available: http://twp.duke.edu/cms/ aMediaBackend/original?slug=delib2011liu\&format=pdf [Accessed 2016-08-09].

MacDonald, WG 1976. 'Pentecostal theology: A classical viewpoint,' in Spittler, R.P. (ed.) Perspectives on the new Pentecostalism, 58-74. Grand Rapids: Baker.

Martin, LR 2015. 'Fire in the bones: Pentecostal prophetic preaching,' in Martin, L.R. (ed.) Toward a Pentecostal theology of preaching, 34-64 . Cleveland: CPT.

McPherson, AS 1946. The foursquare gospel. Los Angeles: Echo Park Evangelistic Association.

Moore, RD 2000. 'A letter to Frank Macchia.' Journal of Pentecostal Theology 17:12-14.

Moore, RD 2011. The Spirit of the Old Testament. JPTS 35. Blandform Forum: Deo.

Morton, B. 2012. [Online]. Available: 'The Devil Who Heals': Fraud and Falsification in the Evangelical Career of John G Lake, Missionary to South Africa 1908-1913. African Historical Review 44(2):98-118. http:// dx.doi.org/10.1080/17532523.2012.739752 [Accessed 2015-05-23].

Olson, RE 1999. The story of Christian theology: Twenty centuries of tradition \& reform. Leicester: Apollos.

Pagitt, D 2005. Preaching re-imagined: The role of the sermon in communities of faith. Grand Rapids: Zondervan.

Parham, CF [1911]2006. 'The everlasting gospel', in Jacobsen, D. (ed.) A reader in Pentecostal theology: Voices from the first generation, 31-44. Bloomington: Indiana University Press.

Ragoonath, A 2004. Preach the word: A Pentecostal approach. Winnipeg: Agape. 
Robeck, CM 2006. The Azusa Street Mission and revival: The birth of the global Pentecostal movement. Nashville: Thomas Nelson.

Robinson, HW 2001. Biblical preaching: The development and delivery of expository messages. Second edition. Grand Rapids: Baker.

Samuel, JPS 2013. 'The Spirit in Pentecostal preaching: A constructive dialogue with Haddon W. Robinson's and Charles T. Crabtree's theology of preaching.' Pneuma 35:199-219.

Seymour, WJ [1915]2006. 'The doctrines and disciplines of the Azusa Street Apostolic Mission of Los Angeles, cal. with Scripture readings', in Jacobsen, D. (ed.) A reader in Pentecostal theology: Voices from the first generation, 45-56. Bloomington: Indiana University Press.

Shaull, R 1998. 'What can the mainline learn from Pentecostals about Pentecost preaching?' Journal for preachers Lent:8-14.

Sheppard, GT 2001. 'Prophecy:' From ancient Israel to Pentecostals at the end of the modern age.' The Spirit \& the church 3(1):47-70.

Smith, R 2008. 'Call and response', in Wilson, P.S. (ed.) The New Interpreter's Handbook of Preaching, 297. Nashville: Abingdon.

Stevens, B 2006. 'Up, up and away': Pentecostal preaching and the manic defence.' Asian Journal of Pentecostal Studies 9(2):284-294.

Stronstad, R 2010. The prophethood of all believers: A study in Luke's charismatic theology. Cleveland: CPT.

Tomlinson, AJ [1913]2006. 'The last great conflict', in Jacobsen, D. (ed.) A reader in Pentecostal theology: Voices from the first generation, 95-108. Bloomington: Indiana University Press.

Waddell, R 2006. The Spirit of the Book of Revelation. JTPSup 30. Blandford Forum : Deo.

Waldholm, R 2015. 'Emerging homiletics: A Pentecostal response,' in Martin, L.R. (ed.) Toward a Pentecostal theology of preaching, 258288. Cleveland: CPT.

Williams, ES 1953. Systematic theology. Vol. 3. Springfield: Gospel Publishing. 
Willimon, WH 1998. 'Suddenly from heaven there came a sound':

Pentecostal preaching at the end of the twentieth century.' Journal for preachers Lent:15-21.

Wood, G 2010. 'The Pentecostal pulpit of the $21^{\text {st }}$ century.' [Online]. Available: http://enrichmentjournal.ag.org/199803/076_Pentecostal_pulpit.cfm [Accessed 2016-08-09].

Yeung, T 2011. 'The characteristics of William Seymour's sermons: A reflection on Pentecostal ethos.' Tr. By C. Au. Asian Journal of Pentecostal Studies 14(1):57-73.

Young, E 2006. 'Preaching creatively,' in Duduit, M (ed.) Preaching with power: Dynamic insights from twenty top pastors, 228-249. Grand Rapids: Baker. 